\title{
Colicin K Decreases the Density of Intramembrane Particles (IMP) in the Cell Membrane of Escherichia coli
}

\author{
By JA N S̆MARDA \\ Department of Biology, Medical Faculty, J. E. Purkyně University, 66243 Brno, Czechoslovakia
}

(Received 10 August 1987; revised 7 November 1987)

\begin{abstract}
Toxic effects of both main colicin types, i.e. of porin and nuclease types, involve the direct contact of their molecules with the plasma membrane of sensitive cells. In the present study, it was tested whether this contact provokes a lateral or vertical movement of intramembrane protein particles (IMP) or a direct cleavage of the proteins. IMP were visualized by freezefracturing and electron microscopy on the protoplasmic fracture face (PF) of colicin-treated cells of Escherichia coli. Possible changes in distribution and in density of IMP due to treatment with colicins E1-E7 and $\mathrm{K}$ were followed. As a control, the bacteria were equilibrated at $0{ }^{\circ} \mathrm{C}$ before quenching, which caused a reversible formation of smooth areas and a decrease in the mean density of IMP on the PF. Colicins E1-E7 had no clear-cut effect on the disposition of IMP. Only colicin K decreased the IMP density, by $10 \%$ in E. coli strain $58-161$ and by $17 \%$ in strain C6; the distribution of IMP remained homogeneous. Trypsin reactivation of colicin-Kinactivated bacteria was not reflected by restoration of the original density of IMP; on the contrary, it led to a further decrease, of $1-13 \%$, in IMP density, presumably by proteolytic cleavage. Varying densities of IMP in different strains of the same bacterial species (under standard conditions) were confirmed.
\end{abstract}

\section{INTRODUCTION}

Colicins are toxic proteins produced by Escherichia coli and related bacterial species. To exert their inhibitory effects, colicin molecules must bind to specific receptors in the surface layers of sensitive cells of the same species. As to their molecular modes of action, most colicins belong to one of two major types: the transmembrane porin type (such as colicins A, B, E1, Ia, Ib, K, Q), or the nuclease type (such as colicins E2-E7) (for reviews, see Šmarda, 1978; Konisky, 1982; Pugsley, $1984 a, b)$.

Colicins of the porin type exert their primary action on the plasma (inner) membrane of sensitive bacterial cells; their molecules form ion-permeable channels across it. In this way, the energized state of the membrane is dissipated. Diverse metabolic changes follow as a consequence of the collapse of the membrane proton-motive force. Nucleic acid and protein biosyntheses are inhibited; and cells lose potassium and magnesium, which may be the direct cause of their death (Kopecky et al., 1975).

Colicins E2 and E7 specifically inhibit DNA synthesis and induce DNA degradation (Nomura, 1963; Ringrose, 1970; Smarda et al., 1988); so they act as DNA endonucleases. Colicins E3-E6 stop protein synthesis; colicin E3 (and maybe all other ribonuclease-type colicins) does so by a direct endonucleolytic cleavage of 16S rRNA (Nomura, 1963; Senior \& Holland, 1971; Smarda et al., 1988). Since the cleaved $3^{\prime}-O H$-terminal rRNA fragment is indispensable for the correct configuration of the aminoacyl-binding site of $70 \mathrm{~S}$ ribosomes, translation ceases. Nevertheless, these colicins, too, must penetrate the cell envelope, including the plasma membrane, to reach their intracellular biochemical targets. This penetration must influence, although transiently, the physico-chemical parameters of the membrane.

Abbreviations: IMP, intramembrane particle(s); PF, protoplasmic fracture face(s). 
Injury to biomembranes, and especially to plasma membranes, may be visualized by electron microscopy after freeze-fracturing. Upon splitting the plasma membrane, two fracture faces are exposed. The protoplasmic fracture face (PF - according to Branton et al., 1975) is usually densely packed with homogeneously distributed protein granules (see Fig. 1a). Agents that alter the physico-chemical properties of the membrane, such as its fluidity, may alter the density of PF particles, their random distribution or even their size and form.

The aim of the present work was to monitor the distribution and density of intramembrane protein particles (IMP) revealed by freeze-fracturing on the PF fracture plane of the plasma membrane of $E$. coli treated with colicins of both the porin type $(\mathrm{E} 1, \mathrm{~K})$ and the nuclease type (E2-E7). Also, the reversibility of changes in IMP density after reactivation of colicin-inhibited cells with trypsin was followed.

\section{METHODS}

Bacterial strains. The following colicin-sensitive $E$. coli strains were used: strain 58-161 metB1 rpsL $(\lambda)$ and strain C6 $(\varphi)$. Both strains were obtained from Professor P. Fredericq, University of Liège, Belgium.

Media. Meat/peptone broth (MPB) contained $0.3 \mathrm{~g}$ beef extract (Difco), $20 \mathrm{~g}$ peptone (Imuna, Šarišské Michal'any, Czechoslovakia) and $5 \mathrm{~g} \mathrm{NaCl}$ in $1000 \mathrm{ml}$ water; the $\mathrm{pH}$ value was adjusted to $7 \cdot 4$. Meat/peptone agar (MPA) was MPB solidified with $2 \%(w / v)$ agar (Lachema, Brno, Czechoslovakia) for base layers or $0.7 \%(w / v)$ agar for top layers (double-layer plates were used for spot-dilution assays of colicins).

Colicins. These were products of $E$. coli producer strains: colicin E1 of strain OSU (Col E1-K30) (from the collection of the Ohio State University); colicin E2 of strain CA42; and colicin E3 of strain CA38-this colicin was a purified product from the Institute of Sera and Vaccines, Prague, Czechoslovakia, with an activity of $2.86 \times 10^{8} \mathrm{LU} \mathrm{\mu g}^{-1}$ (Šmarda, 1978). One lethal unit (LU) is the least amount of colicin necessary to kill one cell of a sensitive indicator strain; throughout this study, strain 58-161 was used as the indicator. Colicin E4 was a product of strain W3110 (Col E4-CT9); colicin E5 of W3110 (Col E5-099); colicin E6 of W3110 (Col E6-CT14); colicin E7 of W3110 (Col E7-K317); and colicin K of strain K49. With the exception of colicin E3, the colicins were used as crude sterile supernates of ultrasonically disintegrated UV-induced producer bacteria in water. Stock lysates, reaching titres of $10^{11}-10^{13} \mathrm{LU} \mathrm{ml} \mathrm{m}^{-1}$, were kept at $+4{ }^{\circ} \mathrm{C}$. E. coli strains CA42, CA38 and K49 were kindly supplied by Professor P. Fredericq, and all the other colicinogenic strains by Dr A. P. Pugsley, Institut Pasteur, Paris, France

Treatment of bacteria with colicins and their reactivation with trypsin. Bacteria (58-161 or C6) from a static overnight MPB culture were washed with $145 \mathrm{mM}$-physiological saline (pH 6.8) and resuspended to a density of $1.5-2.5 \times 10^{10}$ c.f.u. $\mathrm{ml}^{-1}$ (for strain 58-161) or $0.6-1.0 \times 10^{10}$ c.f.u. $\mathrm{ml}^{-1}$ (for strain C6). The suspension was divided into three $1 \mathrm{ml}$ volumes in thin-walled test tubes and prewarmed to $37^{\circ} \mathrm{C}$. At time 0 , sample 1 was mixed with $1 \mathrm{ml}$ physiological saline (prewarmed to $37^{\circ} \mathrm{C}$ ); it served as a control. At the same time, samples 2 and 3 were each mixed with $1 \mathrm{ml}$ of the prewarmed colicin solution to be tested. The dose of colicins was adjusted to 20-30 LU per bacterium for strain 58-161, or to 50-75 LU per bacterium for strain C6. All three samples were incubated at $37{ }^{\circ} \mathrm{C}$ for $10 \mathrm{~min}$. Thereafter, samples 1 and 2 were washed with physiological saline and fixed with $2 \%(\mathrm{v} / \mathrm{v})$ glutaraldehyde in $67 \mathrm{mM}$ (final concentration) Sörensen sodium/potassium phosphate buffer pH $7 \cdot 1$, prewarmed to $37^{\circ} \mathrm{C}$. To sample 3, $0.4 \mathrm{ml} \mathrm{10 \% (w/v)} \mathrm{trypsin} \mathrm{(Boehringer} \mathrm{Mannheim;} \mathrm{pharmaceutical} \mathrm{purity)} \mathrm{solution}$ (prewarmed to $37^{\circ} \mathrm{C}$ ) was added. This mixture was kept for a further $15 \mathrm{~min}$ at $37^{\circ} \mathrm{C}$, then the bacteria were washed and fixed with $2 \%(\mathrm{v} / \mathrm{v})$ prewarmed glutaraldehyde, as for samples 1 and 2 . Fixed samples were kept at $37^{\circ} \mathrm{C}$ for $1 \mathrm{~h}$ before freeze-fracturing (see below). Immediately before fixation, $0.1 \mathrm{ml}$ of each sample was withdrawn to ascertain, after appropriate dilution with physiological saline, the numbers of c.f.u. by plating.

For freeze-fracturing, only those bacterial suspensions were taken in which less than $0 \cdot 1 \%$ of the bacteria survived the colicin treatment and in which the restoration of at least $75 \%$ c.f.u. was achieved by trypsin reactivation.

Cold treatment of bacteria and shift to $37^{\circ} \mathrm{C}$. Cells of strain 58-161 were grown and concentrated in physiological saline as described above. At time 0 , two $1 \mathrm{ml}$ samples in thin-walled test tubes were chilled to $0{ }^{\circ} \mathrm{C}$ and kept for $30 \mathrm{~min}$ at this temperature; the third (control) sample was incubated for $30 \mathrm{~min}$ at $37^{\circ} \mathrm{C}$. Thereafter, one chilled sample and, simultaneously, the control one were fixed with $2 \%(\mathrm{v} / \mathrm{v})$ glutaraldehyde: for the chilled one, the fixative was chilled to $0{ }^{\circ} \mathrm{C}$, and for the control one, it was prewarmed to $37^{\circ} \mathrm{C}$. Both fixed samples were kept at the corresponding temperatures for a further $30 \mathrm{~min}$. The second chilled sample was transferred from $0{ }^{\circ} \mathrm{C}$ to $37^{\circ} \mathrm{C}$ and kept for $30 \mathrm{~min}$ at this temperature. Then it was fixed with glutaraldehyde prewarmed to $37^{\circ} \mathrm{C}$ as described above and kept for a further $30 \mathrm{~min}$ at $37^{\circ} \mathrm{C}$.

Freeze-fracturing. Fixed bacteria were sedimented by centrifugation, washed twice in 67 mM-phosphate buffer, $\mathrm{pH} 7 \cdot 1$, and transferred stepwise to increasing concentrations of glycerol $(5-30 \%, \mathrm{w} / \mathrm{v})$. In this cryoprotectant, pellets were quickly frozen in Freon $22\left(-160^{\circ} \mathrm{C}, 10 \mathrm{~s}\right)$, transferred into liquid nitrogen and, eventually, fractured 
at $-196^{\circ} \mathrm{C}$ and $2 \times 10^{6}$ Torr $(\sim 267 \mu \mathrm{Pa})$ in a Balzers AG BA $360 \mathrm{M}$ unit. Freeze-fracture surfaces were coated with carbon-platinum.

Electron microscopy. Platinum-shadowed carbon replicas were cleaned with $40 \%(\mathrm{v} / \mathrm{v})$ chromic acid for $7 \mathrm{~d}$ and photographed in a Tesla BS500 electron microscope at a direct magnification of $30000 \times$. Pictures of appropriate cells exposing extensive areas of plasma-membrane PF were enlarged photographically to $150000-200000 \times$ final magnification on Document photographic paper. On the enlargement of each cell, a square corresponding to $\frac{1}{8} \times \frac{1}{8} \mu \mathrm{m}^{2}$ was drawn on a flat part of the exposed PF area; IMP were counted in this square.

Statistical evaluation of the results. For each treatment, several tens of cells were evaluated. The mean number of IMP per $0 \cdot 1 \mu \mathrm{m}^{2}$ PF and its sample standard deviation were calculated for each set of results. Besides the mean, the sample was characterized by its dispersion and coefficient of variation. The statistical significance of the mean difference between each experimental set and the corresponding control set was estimated either by the $t$-test or by the $U$-test for $n_{1}, n_{2}>50$, for $5 \%$ and $1 \%$ levels of significance.

\section{RESULTS}

To confirm that $E$. coli 58-161 was an appropriate model system for displaying changes in the distribution and density of IMP following a physico-chemical alteration of the plasma membrane, bacteria that had been exposed to a temperature of $0{ }^{\circ} \mathrm{C}$ for $30 \mathrm{~min}$ were examined first. Striking changes in the random distribution of IMP were evident on the plasma-membrane $\mathrm{PF}$, characterized by extensive 'bald patches' separated by stripes and irregular areas of more condensed granules (Fig. $1 b$ ). At the same time, the mean density of granules per unit area was decreased to $76 \%$ of the control density (Table 1). Most of these changes were reversible through a shift of the cells to $37^{\circ} \mathrm{C}$ : bald patches disappeared and the mean density of granules was restored to $90 \%$ of the original value (Fig. 1c, Table 1 ).

Colicins E1, E2, E5, E6 and E7 had no significant effect either on the distribution or on the density or appearance of IMP on PF of strain 58-161 cells. Colicin E3 caused a small increase (to $105 \%$ of the original count) in IMP per unit area of PF, whereas colicin E4 caused a slight decrease (to $96 \%$ of the original IMP density); both these differences proved significant only at the $5 \%$ level.

The only clear effect was that of colicin $\mathrm{K}$ : the random distribution of IMP remained unaltered, but their density was lowered to $90 \%$ of the control in strain $58-161$ (Fig. $1 d$ ). This finding was also verified in strain $\mathrm{C} 6$, where the density was lowered to $83 \%$ (Table 1 ). In both strains, this decrease was significant $(P<1 \%)$.

Table 1. Differences in IMP density on the plasma-membrane PF caused by various treatments

$\begin{array}{ccc}\text { No. of cells } & \text { Mean no. of IMP } & \begin{array}{c}\text { Coefficient of } \\ \text { variation }(\%)\end{array}\end{array}$

$\begin{array}{llll}\text { Strain } 58-161 & & & \\ \text { None (control) } & 82 & 720( \pm 127) & 17 \cdot 6 \\ \text { Temperature } 0{ }^{\circ} \mathrm{C} & 36 & 648( \pm 129)^{*} & 23 \cdot 5 \\ \text { Shift } 0{ }^{\circ} \mathrm{C} \text { to } 37^{\circ} \mathrm{C} & 26 & 762( \pm 127) & 11 \cdot 2 \\ \text { Colicin E1 } & 55 & 645( \pm 109)^{*} & 16 \cdot 7 \\ \text { Colicin E1, then trypsin } & 79 & 640( \pm 109)^{*} \dagger & 14 \cdot 8 \\ \text { Colicin K } & 71 & & 16 \cdot 9 \\ \text { Colicin K, then trypsin } & 72 & 811( \pm 107) \ddagger & \\ \text { Strain C6 } & & 677( \pm 149)^{*} & 13 \cdot 2 \\ \text { None (control) } & 40 & 600( \pm 64)^{*} \dagger & 22.0 \\ \text { Colicin K } & 138 & & 10 \cdot 7 \\ \text { Colicin K, then trypsin } & 38 & \end{array}$

* The difference in the mean number of IMP from that of untreated (control) cells of the strain given is significant $(P<1 \%)$.

$\dagger$ The difference in the mean number of IMP from that of cells of the strain given treated as stated in the previous line is significant $(P<1 \%)$.

$\ddagger$ The difference between the IMP densities on PF of bacteria of strains $58-161$ and C6 is significant $(P<1 \%)$. 

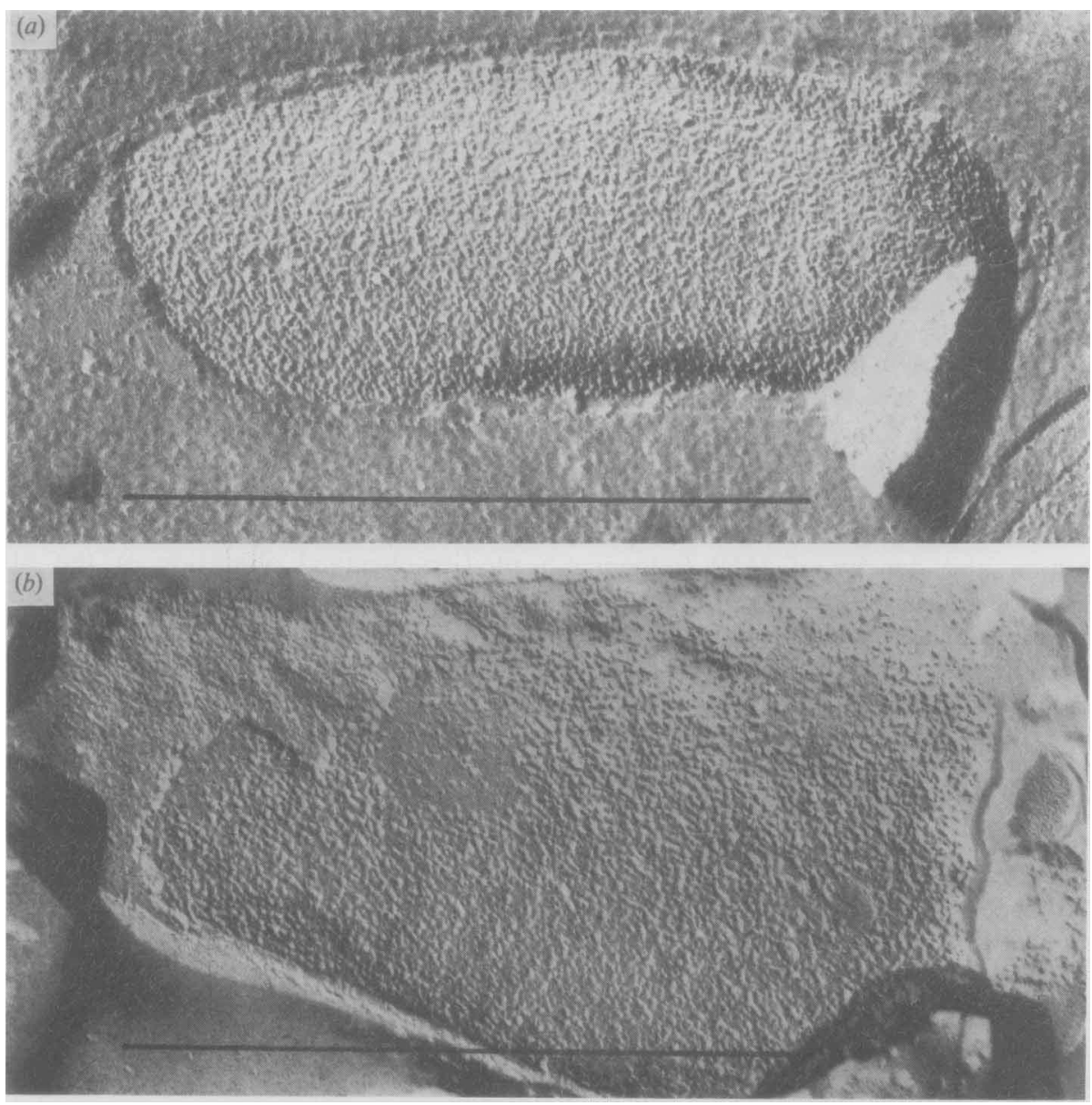

Fig. 1 (continued on facing page). Plasma-membrane PF of cells of $E$. coli strain 58-161. Bars, $1 \mu \mathrm{m} .($ a) Control cell with homogeneously distributed IMP. (b) Cell exposed to $0{ }^{\circ} \mathrm{C}$ for $30 \mathrm{~min}$; 'bald patches' are formed. (c) Cell exposed to $0^{\circ} \mathrm{C}$ for $30 \mathrm{~min}$ and shifted to $37^{\circ} \mathrm{C}$; homogeneous distribution of IMP has been restored. $(d)$ Cell exposed to colicin $\mathrm{K}$ for $10 \mathrm{~min}$ at $37^{\circ} \mathrm{C}$; the density of IMP was decreased to $90 \%$ of the control value.

The restoring effect of trypsin on bacteria inhibited with colicin El (in strain 58-161) and with colicin K (in strains 58-161 and C6) was also investigated. In all three systems, trypsin treatment caused an additional slight decrease in the density of IMP. In colicin-E1-treated 58-161, this decrease was insignificant. Amounting to only $1 \%$, it was also insignificant in colicin-K-treated 58-161. However, in the more densely covered PF of colicin-K-treated C6 bacteria, the decrease reached $11 \%$ and was significant $(P<1 \%)$.

The cells of strain C6 are, in general, slightly smaller than those of strain 58-161; also their growth rate in cultures is lower. However, the density of IMP on the PF of their plasma membrane is significantly higher than that on the PF of cells of strain 58-161 (Table 1).

\section{DISCUSSION}

Lateral diffusion of IMP resulting in a segregation of small IMP-free and aggregated-IMP areas due to a bacteriocin was first noticed on plasma-membrane PF of Staphylococcus aureus treated with staphylococcin A (Šmarda \& Obdržálek, 1981). The circular smooth areas on 

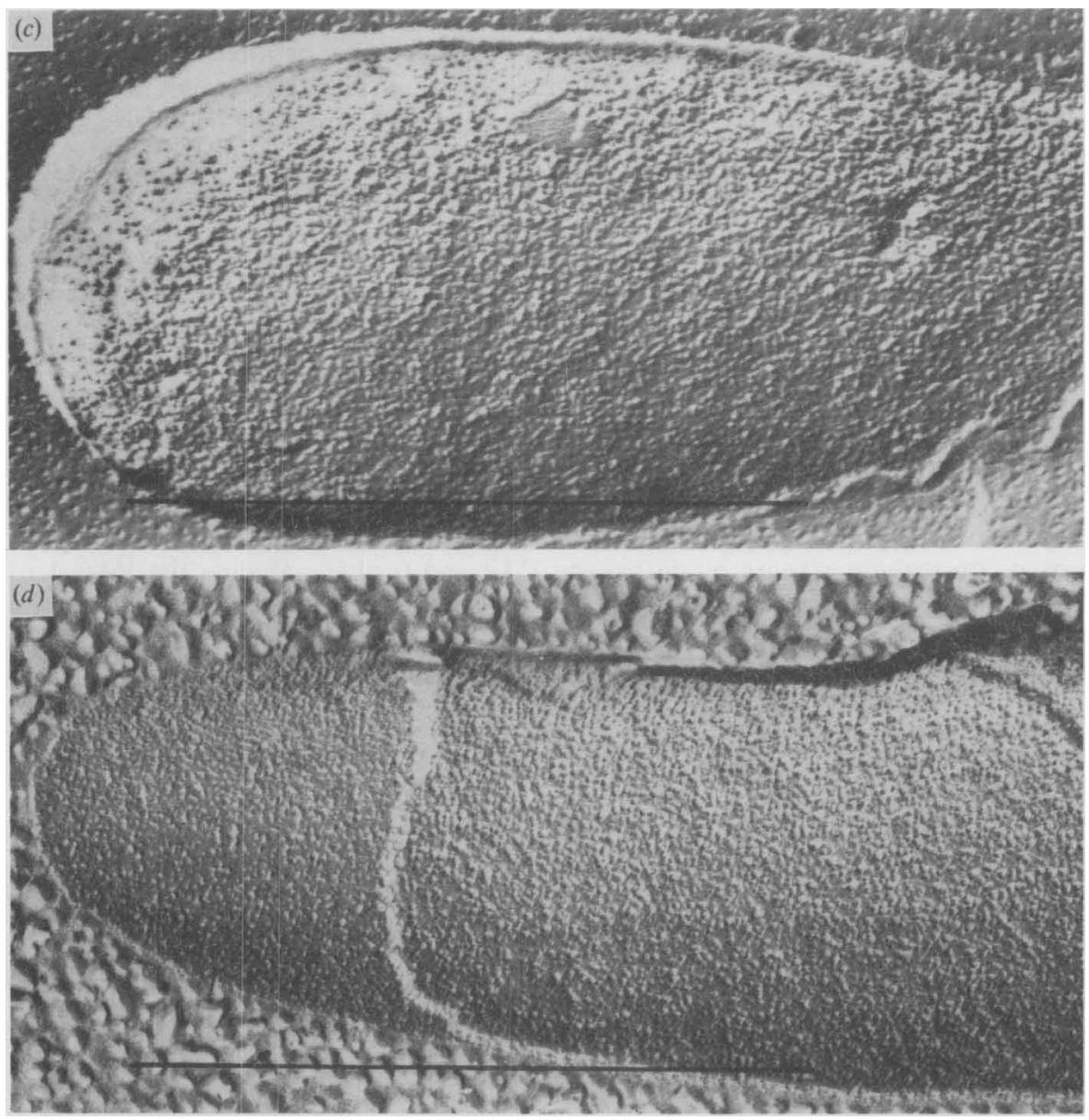

plasma-membrane PF found previously in E. coli $\mathrm{C} 6$ cells treated with colicin K, but not fixed before transfer to $20 \%$ glycerol (Šmarda, 1978), could not be seen in the present study on glutaraldehyde-fixed 58-161 and C6 cells; they were thus most probably provoked by glycerol (see Arancia et al., 1980) and not by colicin K (although they were not recognizable in cells not treated with colicin K).

Also, in the hundreds of $E$. coli $58-161$ cells treated with colicins E1-E7, no indication of smooth areas could be found. Typical IMP-free areas were observed only in bacteria chilled to $0{ }^{\circ} \mathrm{C}$; these disappeared when the temperature was shifted back to $37^{\circ} \mathrm{C}$. Thus it may be assumed that none of the eight colicins tested acts either as a detergent, as a protease, or as a phospholipase on the plasma membrane of sensitive bacteria, and that none of them causes a lipid phase transition ordering hydrocarbon chains of membrane phospholipids.

Mühlethaler et al. (1965), Remsen et al. (1967), Staehelin (1968), Branton (1969) and others have postulated an increased density of IMP to be a symptom (and a prerequisite) of a more active functional state of the membrane. Matsusaka \& Ishida (1977) found, in E. coli K 12 strain W1895, 830 IMP per $0.1 \mu \mathrm{m}^{2}$ PF under aerobic, but only 300 IMP under anaerobic conditions. Arancia et al. (1980) found that in E. coli K 12, the mean number of IMP per PF unit area was decreased by $24 \%$ following chilling of the cells; and we found precisely the same mean decrease in overall IMP density following chilling of $E$. coli 58-161 bacteria. 
It must be taken into account that any quantitative analysis of IMP density is susceptible to considerable subjective and objective errors, and the results must be interpreted with caution. Thus the difference between any mean IMP numbers must be considered insignificant if it holds only at the $5 \%$ level of significance. Hence, the increase in IMP density following treatment with colicin E3 and its decrease after treatment with colicin E4 must be neglected. Only colicin K caused a significant decrease in IMP density on membrane PF : by $10 \%$ in $58-161$ and by $17 \%$ in C6 bacteria.

Changes in IMP density may be explained by a vertical movement of particles within the membrane (Niedermeyer et al., 1976). Generally, the density increases during osmotic swelling of the cell, as IMP hitherto embedded in the lipid bilayer move to the surface of the hydrophobic leaflet of the membrane monolayer; conversely, IMP density decreases during osmotic shrinking (Nečas et al., 1981). Obviously, the movement into this leaflet must take place during the first, reversible phase of colicin $\mathrm{K}$ inhibition of bacteria. Thus there must be an effect on the plasma membrane before channel-forming colicin $\mathrm{K}$ molecules become irreversibly inserted into it. However, reactivation with trypsin of bacteria in the first, reversible, phase of colicin $\mathrm{K}$ inhibition is not reflected in the restoration of the original IMP density. On the contrary, trypsin manifests its proteolytic activity by destroying IMP and further reducing the IMP density.

No analogous effect of colicin El could be found, although, like colicin $\mathrm{K}$, it forms ionpermeable channels by insertion into the plasma membrane. This suggests that the first phase of action is different for colicins $\mathrm{E} 1$ and $\mathrm{K}$, presumably due to their having different receptors.

The author wishes to express his thanks to Dr H. Koukalová for the skilled and careful statistical processing of the experimental results.

\section{REFERENCES}

Arancia, G., Valente, F. R. \& Crateri, P. T. (1980). Effect of glutaraldehyde and glycerol on freezefractured Escherichia coli. Journal of Microscopy 118, 161-176.

Branton, D. (1969). Membrane structure. Annual Review of Plant Physiology 20, 209-238.

Branton, D., Bullivant, S., Gilula, N. B., KarNOVSKY, M. J., MoOR, H., MÜHLETHALER, K., Northcote, D. H., PACKer, L., SAtiR, B., SAtir, P., Speth, V., Staehelin, L. A., Steere, R. L. \& WEINSTEIN, R. S. (1975). Freeze-etching nomenclature. Science 190, 54-56

Konisky, J. (1982). Colicins and other bacteriocins with established modes of action. Annual Review of Microbiology 36, 125-144.

KOPECKY, A. L., COPELAND, D. P. \& LuSK, J. E. (1975). Viability of Escherichia coli treated with colicin K. Proceedings of the National Academy of Sciences of the United States of America 72, 46314634.

Matsusaka, T. \& Ishida, A. (1977). A freeze-fracture study on the membrane-associated particles of aerobically and anaerobically grown Escherichia coli. Journal of General and Applied Microbiology 23, 275 277.

Mühlethaler, K., MoOR, H. \& Szarkowski, J. W. (1965). The ultrastructure of the chloroplast lamellae. Planta 67, 305-323.

Nečas, O., Svoboda, A. \& Pivničková, E. (1981). Plasma membrane particles in yeast protoplasts Acta histochemica (suppl). 23, 151-155.

Niedermeyer, W., Parish, G. R. \& MoOR, H. (1976). The elasticity of the yeast cell tonoplast related to its ultrastructure and chemical composition. I. Induced swelling and shrinking; a freeze-etch membrane study. Cytobiology 13, 364-379.
Nomura, M. (1963). Mode of action of colicines. Cold Spring Harbor Symposia on Quantitative Biology 28, 315-324.

Pugsley, A. P. (1984a). The ins and outs of colicins. Part I. Production, and translocation across membranes. Microbiological Sciences 1, 168-175.

Pugsley, A. P. (1984b). The ins and outs of colicins. Part II. Lethal action, immunity and ecological implications. Microbiological Sciences 1, 203-205.

Remsen, C. C., Hess, W. M. \& Sassen, M. M. (1967). Fine structure of germinating Penicillium megasporum conidia. Protoplasma 64, 439-451.

RINGrose, P. (1970). Sedimentation analysis of DNA degradation products resulting from the action of colicin $\mathrm{E}_{2}$ on Escherichia coli. Biochimica et biophysica acta 213, 320-334.

Senior, B. W. \& Holland, I. B. (1971). Effect of colicin E3 upon the $30 \mathrm{~S}$ ribosomal subunit of Escherichia coli. Proceedings of the National Academy of Sciences of the United States of America 68, 959963.

SMARDA, J. (1978). The Effects of Colicins. Brno: J. E. Purkyně University.

ŠMARDA, J. \& OBdRŽÁLEK, V. (1981). Staphylococcins: incidence and some characteristics of antibiotic action. In Staphylococci and Staphylococcal Infections, pp. 407-411. Edited by J. Jeljaszewicz. Stuttgart \& New York: Gustav Fischer Verlag.

Šmarda, J., Uher, P., Osecký, P. \& ŠMARda, JAROSLAV (1988). Modes of action of colicins E4-E7: rates of basic biosyntheses inhibition. Zentralblatt für Bakteriologie, Mikrobiologie und Hygiene (Abteilung $A$ ) (in the Press).

StaEHELIN, L. A. (1968). The interpretation of freezeetched artificial and biological membranes. Journal of Ultrastructure Research 22, 326-347. 